\title{
Willow planting success as influenced by site factors and cattle grazing in northeastern California
}

\author{
SCOTT D. CONROY AND TONY J. SVEJCAR
}

\section{Abstract}

In recent years there has been an increasing emphasis on reestablishment of woody vegetation in degraded riparian zones. In this study we evaluated the influence of grazing and selected site factors on survival and leader growth of planted Geyer willow (Salix geyeriana Anderss.) cuttings. Three grazing treatments (early summer, late summer, and non-use) were evaluated on each of 3 streams in broad, low-gradient meadows with silt loam soils in the northern Sierra Nevada. The streams were perennial with terraces often 1.0 to $1.5 \mathrm{~m}$ above streambottom. Unrooted Geyer willow cuttings were planted to $30-\mathrm{cm}$ soil depth in early May 1987 at 3 streamchannel locations (streambottom, streambank, and stream terrace) within each of the grazing treatments. Survival, associated community type, and cover class were determined for 2,700 plantings. Leader length and grazing intensity were measured for 694 surviving cuttings in 1988. Percent soil moisture and water table depth were determined for a subset of the willow cuttings. There was no significant $(P>0.05)$ effect of grazing treatment on either willow survival or growth despite 3.5 to 5 times more defoliation use of the willow cuttings in the grazed pastures. Streamchannel location did significantly $(P \leq 0.05)$ affect willow survival (streambottom $=83 \%$, streambank $=34 \%$, and stream terrace $=3 \%$ ) but not individual plant leader length. Survival of willow cuttings for Carex nebrascensis/Juncus nevadensis, bareground, Deschampsia caespitosa/Carex nebrascensis, and A rtemisia sp. dominated sites was 76, 60, 44, and $2 \%$, respectively. However, leader length was significantly ( $P \leq 0.05)$ greater for bareground sites than for sites supporting vegetation. Cover class was not a good indicator of survival, but as might be expected from the results on the bareground sites, leader length for the 0-5\% class was 1.8 times the length of the next class. There was a clear relationship between water table depth, soil moisture, and willow planting survival but not between moisture measurements and leader length. Once the water table has declined to the point that Artemisia sp. can survive on a site, the chances of successfully replanting willows are minimal. However, even during the drought years of this study ( $<50 \%$ of average annual precipitation) a survival rate of $60 \%$ or greater was achieved by planting into Carex nebrascensis communities or bareground in the streamchannel.

Key Words: soil moisture, water table, survival, riparian, Salix geyeriana

Improper use of riparian ecosystems by cattle can change, reduce, or eliminate vegetation bordering streams (Kauffman and Krueger 1984). This often leads to erosion, bankcutting, and lowering of the water table, which contributes to the loss of many riparian plant species (Marlow 1987). Riparian zones altered by widened channels, frequent channel realignments, and poorly vegetated banks and floodplains can be rehabilitated by reestab-

\footnotetext{
Authors are range conservationist, USDA-Forest Service, P.O. Box 7, Blairsden, California 96103; and range scientist, USDA-Agricultural Research Service, 920 Valley Road, Reno, Nevada, 89512. Reprint requests should be sent to Svejcar's current address: USDA-ARS, HC 71 4.51 Hwy 205, Burns, Oregon 97720. At the time of the research, Conroy was a graduate assistant at University of Nevada, Reno. The authors thank W.S. Platts, S. Swanson, G.F. Gifford, S. Jenkins, and J. Trent for their sugfestions during the course of the research. Constructive comments on the Manuscript accepted 18 May 1990.
}

lishing plants in the riparian streamside zone (VanHaveren and Jackson 1986). Establishment of woody plants is critical in the restoration of many riparian areas (Volny 1984). Methods for interplanting woody species onto unstable streambanks have not been fully developed and need further study (Platts et al. 1987, Skovlin 1984). Willow (Salix sp.) transplants are recommended because they are usually locally available, native, easily established, relatively inexpensive to plant, provide more stability to the site than many other woody plants, and grow rapidly (Schultze and Wilcox 1985, Gray et al. 1984).

Success of willow planting can be affected by grazing (Eckert 1975, Platts et al. 1987), soil moisture (Platts et al. 1987, Fege 1983), and species of willow planted (Platts et al. 1987). The objectives of this study were to determine survival and growth of unrooted Geyer willow (Salix geyeriana Anderss.) cuttings as influenced by time of grazing and site factors.

\section{Materials and Methods}

\section{Study Site}

The study was conducted during 1987 and 1988 on the east slope of the northern Sierra Nevada near Lake Davis in Plumas County, California, at an elevation of 1,765 meters. Study sites were located at $10 \mathrm{~km}$ north of the town of Portola. Pastures were located at 3 Lake Davis tributaries: Cow, Freeman, and Big Grizzly creeks. Species in the riparian zones include silver sagebrush (Artemisia cana Pursh $)^{1}$, mountain big sagebrush ( $A$. tridentata var. vaseyana Nutt.), Nebraska sedge (Carex nebrascensis Dewey), tufted hairgrass (Deschampsia caespitosa (L.) Beauv.), Kentucky bluegrass (Poa pratensis L.), Sandberg bluegrass (Poa sandbergii Vasey), Nevada rush (Juncus nevadensis Wats.), and Geyer willow. Soils are moderately well-drained silt and silt loams. The 29-year mean annual precipitation is $96 \mathrm{~cm}, 85 \%$ occurring between October and April mainly as snow. Precipitation was $50 \%$ and $46 \%$ of the 29-year mean during 1987 and 1988, respectively. Spring typically brings rain on snow, which results in large peak streamflows that overtop the streambanks. Streamflow is typically less than $\mathbf{1 0 0}$ $\mathrm{m}^{3} / \mathrm{h}$ during late summer and streams may have intermittant flows during dry years. The mean daily minimum and maximum air temperatures between May and October during the 2-year period were $0^{\circ} \mathrm{C}$ and $24^{\circ} \mathrm{C}$, respectively. The mean soil temperature at 15 $\mathrm{cm}$ depth between May and August was $16^{\circ} \mathrm{C}$. The study sites were historically heavily grazed season-long by cattle. Freeman and Big Grizzly creeks were fenced to exclude livestock in 1985 and 1986 , respectively. Reaches of Cow, Freeman, and Big Grizzly creeks are classified as C3, C6, and F4 stream types (Rosgen 1985). Streambottoms were downcut 1.0 to $1.5 \mathrm{~m}$ below the stream terrace, and the width cut by the stream ranged from about 4 to $10 \mathrm{~m}$.

\section{Willow Planting}

Willow cuttings were planted on a transect line intercept system (Platts et al. 1983). Thirty transects, spaced $3 \mathrm{~m}$ apart, were located downstream from a random point in each pasture. Each transect was perpendicular to the general stream axis, crossed the stream, 
Table 1. Pasture size, stocking rates, forage standing crop means and standard errors (in parentheses), and comparison of 1988 to 1987 forage standing crop.

\begin{tabular}{|c|c|c|c|c|c|c|}
\hline \multirow{2}{*}{ Pasture } & \multirow[t]{2}{*}{$\begin{array}{l}\text { Area } \\
\text { (ha) }\end{array}$} & \multicolumn{2}{|c|}{$\begin{array}{c}\text { Stocking rate } \\
\text { (ha/AUM) }\end{array}$} & \multicolumn{2}{|c|}{$\begin{array}{l}\text { Forage standing crop } \\
(\mathrm{kg} / \mathrm{ha})\end{array}$} & \multirow[t]{2}{*}{$\begin{array}{l}1988 \text { Forage } \\
\text { standing crop } \\
\text { (\% of 1987) }\end{array}$} \\
\hline & & -1987 & $-1988-$ & & $--1988-$ & \\
\hline $\begin{array}{l}\text { Ungrazed } \\
\text { Grazed Early } \\
\text { Grazed Late }\end{array}$ & $\begin{array}{l}2.7 \\
2.7 \\
2.7\end{array}$ & $\begin{array}{l}\overline{1.1} \\
0.8\end{array}$ & $\begin{array}{l}\overline{1.2} \\
1.1\end{array}$ & $\begin{array}{r}1,864(114) \\
541(79) \\
658(42)\end{array}$ & $\begin{array}{l}700(62) \\
369(17) \\
335(13)\end{array}$ & $\begin{array}{l}38 \\
68 \\
51\end{array}$ \\
\hline $\begin{array}{l}\text { Big Grizzly Creel } \\
\text { Ungrazed } \\
\text { Grazed Early } \\
\text { Grazed Late }\end{array}$ & $\begin{array}{l}1.6 \\
4.0 \\
3.5\end{array}$ & $\begin{array}{l}\overline{0.9} \\
0.6\end{array}$ & $\begin{array}{l}\overline{1.2} \\
1.0\end{array}$ & $\begin{array}{l}5,151(302) \\
1,128(105) \mathrm{a}^{1} \\
419(49) \mathrm{b}\end{array}$ & $\begin{array}{r}2,858(180) \\
457(24) \\
462(34)\end{array}$ & $\begin{array}{r}55 \\
41 \\
110\end{array}$ \\
\hline
\end{tabular}

'Standing crop means for grazed pastures within years and streams with different letters differ at $P \leq 0.05$.

and extended $10 \mathrm{~m}$ from the top of both banks. Ten unrooted willow cuttings were planted in the same relative locations on each transect. Thus, there were 300 cuttings per pasture or 2,700 for the entire experiment.

The willow cuttings were collected from onsite $2+$ year-old stems of Geyer willow shrubs the first week of April 1987 just before bud flush, as recommended by Fege (1983) and Platts et al. (1987). Mean diameter and length of the cuttings was $10.5 \mathrm{~mm}$ and 42.3 $\mathrm{cm}$, respectively. Cuttings were stored at $0^{\circ} \mathrm{C}$ for 1 month, then soaked 2 days in water as recommended by Petersen and Phipps (1976) and planted vertically with $30 \mathrm{~cm}$ below ground during the first week of May, 1987. Survival of willow cuttings, total leader length, and number of grazed primary branches were recorded during September 1987 and 1988. Cuttings were considered alive if any aboveground growth was visible, and total leader length was the sum of all shoots growing from the cutting.

\section{Grazing Treatments}

A randomized complete block model was used for the grazing study. Nine pastures were fenced, 3 each on Cow, Freeman, and Big Grizzly creeks with early and late summer grazed and ungrazed treatments randomly assigned within blocks. Typically, seasonlong grazing has been from 20 June to 20 September on these particular allotments. Thus, the early and late grazing periods in 1987 were 22 June to 7 August and 4 August to 23 September, respectively. In 1988 the grazing periods were 21 June to 1 July and 18 August to 31 August, respectively. Initial stocking rates were based on estimated production, and stocking rates were adjusted during the grazing period to obtain similar use on grazed pastures within blocks. Standing crop of forage species was estimated using the comparative yield method (Haydock and Shaw 1975). Pastures size, stocking rates, and forage standing crop are presented in Table 1.

\section{Environmental Factors}

The microsite ( $30-\mathrm{cm}$ radius) associated with each willow cutting was classified in 3 ways: (1) planting location was described as streambottom, streambank, or stream terrace; (2) community type was described as Nebraska sedge/Nevada rush, tufted hairgrass/Nebraska sedge, silver sagebrush/Sandberg bluegrass, mountain big sagebrush/Sandberg bluegrass, or bareground; and (3) cover class of associated vegetation was ocularly estimated at $0-5 \%$, $6-25 \%, 26-50 \%, 51-75 \%$, or 76-100\%. The streambottoms' location was within $0.5 \mathrm{~m}$ of the edge of the stream during early summer flow, the streambank location was about halfway between the stream edge and the beginning of the stream terrace, and the stream terrace is the floodplain that existed before the stream downcut.

Volumetric moisture content of the soil was determined at 15 , 30 , and $60 \mathrm{~cm}$ depths using the neutron scattering method. Installation of the neutron probe soil tubes and calibration of the Campbell Pacific Nuclear Model $503^{2}$ hydroprobe were done according to Brakensiek et al. (1979). Water table levels were monitored using perforated PVC observation wells installed to a $150-\mathrm{cm}$ depth. The neutron probe soil tubes and the observation wells were installed within $30 \mathrm{~cm}$ of 5 willow cuttings along 2 randomly selected transects per pasture. Soil moisture and water table levels were measured for this subset of 90 sites (10 per pasture) 6 times from May through August about every 3 weeks in 1987 and 1988.

\section{Data Analysis}

The data were analyzed using the general linear models (GLM) procedure in SAS (SAS 1985). Two-way analysis of variance models were used for location by grazing treatment, community type by grazing treatment, and cover class by grazing treatment. Because of the number of sampling points for a given community type or cover class was not equal among treatments, we analyzed these data using the GLM procedure for unequal sample size and by averaging values for each community type and cover class within a pasture. The 2 analyses yielded the same statistical results, indicating that no bias was introduced by having unequal sample sizes. All treatment comparisons were made using the LSD $(P<0.05)$ test.

\section{Results}

\section{Year Effect}

Most of the cuttings that survived to the end of the first growing season also survived to the end of the second season. Of the total 2,700 cuttings, $32 \%$ were alive in September 1987 , and $26 \%$ were alive in September 1988. Because potential long-term survival is of interest, we will present survival and growth data from 1988, the second growing season.

\section{Cattle Grazing}

Survival and total leader length of the willow cuttings were not significantly different for the grazing treatments (Table 2); thus subsequent analyses are averaged over grazing treatment, except in cases where a significant interaction occurred. The number of grazed primary leaders was significantly less for the ungrazed

${ }^{2}$ Mention of trade name does not indicate endorsement by the USDA. 
Table 2. Survival (\%), total leader length (cm), number of grazed leaders, and average leader length $(\mathrm{cm})$ means and standard errors (in parentheses) for unrooted willow plantings by grazing treatment.

\begin{tabular}{llcl}
\hline \hline Response variable & Ungrazed & Grazed early & Grazed late \\
\hline Survival (\%) & $33(8)$ & $18(1)$ & $26(4)$ \\
Total Leader Length (cm) & $61(2)$ & $91(39)$ & $77(27)$ \\
No. Grazed Leaders & $0.2(0.0) \mathrm{a} 1$ & $0.7(0.1) \mathrm{b}$ & $1.0(0.1) \mathrm{b}$ \\
Avg. Leader Length (cm) & $29(2)$ & $32(10)$ & $28(8)$ \\
\hline
\end{tabular}

IRow means with different letters differ at $P \leq 0.05$.

pastures than the grazed pastures. We noted deer tracks in the streambottoms, which might explain some of the leader removal in the ungrazed pastures. Average primary leader length was not different among grazing treatments.

\section{Environmental Factors}

Survival differed ( $P \leq 0.05$ ) among the 3 planting locations, being highest in the streambottom and lowest on the stream terrace (Table 3). Differences in leader length between planting locations were not significant.

Table 3. Survival (\%) and leader length (cm) means and standard errors (in parentheses) for unrooted willow plantings by community type and planting location. Data was collected at the end of the second growing season; a total of 2,700 willows were planted.

\begin{tabular}{lcc}
\hline \hline & Survival (\%) & Leader length (cm) \\
\hline $\begin{array}{l}\text { Community type } \\
\text { Cane/June' }\end{array}$ & $76(6) \mathrm{a}^{2}$ & $64(13) \mathrm{b}$ \\
Bareground & $60(13) \mathrm{b}$ & $108(17) \mathrm{a}$ \\
Dece/Cane & $44(8) \mathrm{b}$ & $46(5) \mathrm{b}$ \\
Arca/Posa & $2(1) \mathrm{c}$ & - \\
Artr/Posa & $2(1) \mathrm{c}$ & - \\
Location & & \\
Streambottom & $83(2) \mathrm{a}$ & $87(23)$ \\
Streambank & $34(7) \mathrm{b}$ & $62(10)$ \\
Stream terrace & $3(1) \mathrm{c}$ & $46(5)$ \\
\hline
\end{tabular}

Cane = Carex nebrascensis; June $=$ Juncus nevadensis; Dece $=$ Deschampsia caespi tosa; Posa $=$ Poa sandbergii Arca = Artemisia cana Artr $=A$. tridentata var. vaseyana . ${ }^{2}$ Both grazing treatment by community type, and grazing treatment by location analyses were conducted. Neither interaction terms nor grazing treatment effects were significant $\left(P_{0.05}\right)$ for either analysis; therefore, we have presented means averaged significant $\left(P_{0.05}\right)$ for either analysis; therefore, we have presented means averaged
over grazing treatment. Different letters indicate treatment separation $(P<0.05)$ over grazing treatment. Different lete
within community types or location.

Survival of willow cuttings differed among community types (Table 3). Survival was highest for the Nebraska sedge/Nevada rush community type and lowest for the 2 sagebrush community types. The bareground sites had the longest leader length, about 1.7 and 2.3 times as long as lengths in the Nebraska sedge/Nevada rush and tufted hairgrass/Nebraska sedge community types respectively (Table 3 ).

Survival was highest for the 76-100\% cover class in the ungrazed pastures but highest for the $0-5 \%$ cover class in the early grazed pastures (Table 4). This probably explains the grazing treatment by cover class interaction. Differences in survival by cover class in the late grazed pastures were not significant. Leader length decreased as cover class increased. The $0-5 \%$ cover class had 1.8 to 3.1 times longer leaders than the other cover classes.

Soil moisture and water table depth analyses for all measurement dates yielded similar results. However, the soil moisture and water table depth measurements taken 75 days after planting appeared to best explain the survival results at the water measurement stations. Soil moisture, water table depth, and survival of the subset of willows planted at the water measurement stations were highest on the steambottom, intermediate on the streambank, and lowest on the stream terrace (Table 5). Leader length differences
Table 4. Survival (\%) and leader length (cm) means and standard errors (in parentheses) for unrooted willow plantings by grazing treatment and cover class (\%) of vegetation within $30 \mathrm{~cm}$. There was a grazing treatment by cover class interaction for survival, but not for leader length. Data was collected at the end of the second growing season; a total of 2,700 willows were planted.

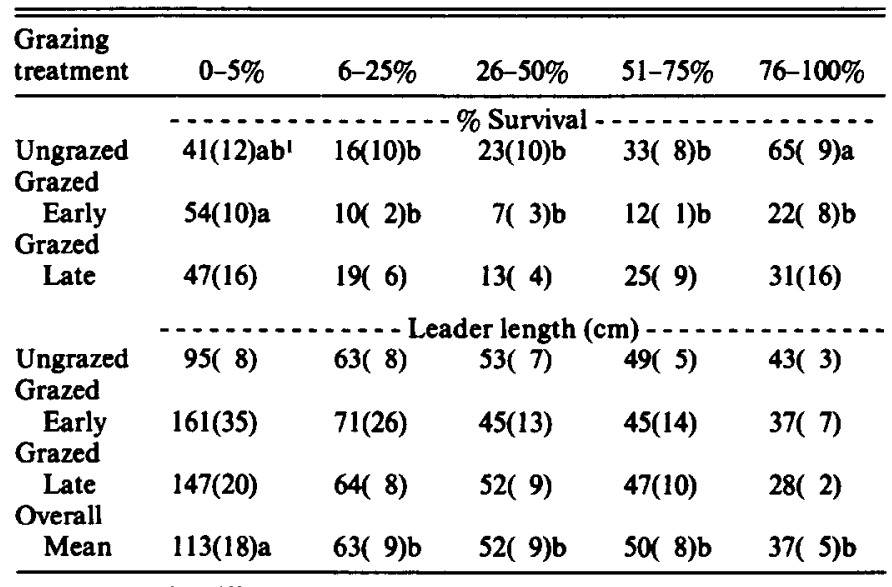

'Row means with different letters differ at $P \leq 0.05$.

were not significant among locations even though leader lengths of streambottom cuttings were at least 2.5 times those of the other 2 locations.

Soil moisture and water table depth were highest for the Nebraska sedge/Nevada rush, tufted hairgrass/Nebraska sedge, and bareground community types (Table 5). Leader length differences at the water measurement stations were not significant, even though bareground willow planting leader length was at least 1.9 times leader lengths in the sedge community types. Survival of willow cuttings in the bareground sites was about twice that of the tufted hairgrass/ Nebraska sedge community type even though soil moisture and water table depth were lower in the bareground sites. The 2 sagebrush community types had the lowest soil moisture and survival, and deepest water table. There were too many plots in the sagebrush community types with $0 \%$ survival to compare leader lengths with the other community types.

No significant differences were found for soil moisture, water table depth, survival, or leader length for the willow cutting subset at the water measurement stations among cover classes, although leader lengths for the $0-5 \%$ and 6-25\% cover classes were 5 and 2.5 times longer, respectively, than those of the other cover classes (Table 5).

\section{Discussion}

Grazing of willow cuttings is generally considered detrimental to establishment (Eckert 1975, Platts et al. 1987). However, in this study we did not find a significant grazing effect on survival of planted willows. The willow cuttings were defoliated 3.5 to 5 times more in the grazed pastures compared to the ungrazed pastures, but this use did not appear to significantly affect survival or leader length. It is possible that carbohydrate reserves in the cuttings were sufficient to offset grazing effects on survival during the first 2 years (Fege and Brown 1984) or that frequency of defoliation of the willow cuttings was low enough for grazing not to be a factor (Taylor 1986). Grazing intensity apparently was light enough to not be harmful to the cuttings. Defoliation in the ungrazed pastures was attributed primarily to deer. There is some indication that grazing may have resulted in an increased number of leaders but the difference was not significant. Cattle diet selectivity tends towards shrubs during the latter part of the grazing season as the herhaceous forage matures (Roath and $\mathrm{K}$ mueger 1982) or hecomes 
Table 5. Water table depth (cm) and soil moisture (\% volume at $30 \mathrm{~cm}$ depth) means and standard errors (in parentheses) on 17 July 1987. Second year survival (\%) and leader length $(\mathrm{cm})$ means and standard errors for unrooted willows planted at the same measurement sites $(\mathrm{n}=90)$.

\begin{tabular}{|c|c|c|c|c|c|}
\hline & \multicolumn{5}{|c|}{ Community type } \\
\hline & Cane / June ${ }^{1}$ & Bareground & Dece/Cane & Arca / Posa & Artr/Posa \\
\hline \multirow[t]{3}{*}{$\begin{array}{l}\text { Water table depth }(\mathrm{cm}) \\
\text { Soil moisture }(\% \mathrm{v}) \\
\text { Survival }(\%) \\
\text { Leader length }(\mathrm{cm})\end{array}$} & $\begin{array}{l}41(13) \mathrm{a}^{2} \\
51(6) \mathrm{a} \\
64(12) \mathrm{a} \\
90(17)\end{array}$ & $\begin{array}{l}73(12) \mathrm{b} \\
43(8) \mathrm{ab} \\
52(2) \mathrm{a} \\
170(50)\end{array}$ & $\begin{array}{l}64(6) \mathrm{ab} \\
54(10) \mathrm{a} \\
22(12) \mathrm{b} \\
61(33)\end{array}$ & $\begin{array}{c}121(2) c \\
36(4) b c \\
6(6) b \\
-\end{array}$ & $\begin{array}{r}122(9) c \\
30(1) c \\
8(8) b \\
-\end{array}$ \\
\hline & \multicolumn{5}{|c|}{ Cover class } \\
\hline & $0-5 \%$ & $6-25 \%$ & $26-50 \%$ & $51-75 \%$ & $76-100 \%$ \\
\hline $\begin{array}{l}\text { Water table depth }(\mathrm{cm}) \\
\text { Soil moisture }(\% \mathrm{v}) \\
\text { Survival (\%) } \\
\text { Leader length }(\mathrm{cm})\end{array}$ & $\begin{array}{r}80(10) \\
43(7) \\
48(6) \\
172(53)\end{array}$ & $\begin{array}{r}89(12) \\
37(5) \\
34(6) \\
109(38)\end{array}$ & $\begin{array}{c}112(15) \\
37(6) \\
14(14) \\
-\end{array}$ & $\begin{array}{l}98(29) \\
45(10) \\
25(13) \\
47(19)\end{array}$ & $\begin{array}{l}70(17) \\
46(6) \\
32(15) \\
34(6)\end{array}$ \\
\hline \multirow{2}{*}{ Leader length (cm) } & \multicolumn{5}{|c|}{ Location } \\
\hline & \multicolumn{2}{|c|}{ Streambottom } & \multicolumn{2}{|c|}{ Streambank } & Stream Terrace \\
\hline $\begin{array}{l}\text { Water table depth }(\mathrm{cm}) \\
\text { Soil moisture }(\% \mathrm{v}) \\
\text { Survival }(\%) \\
\text { Leader length }(\mathrm{cm})\end{array}$ & & & & & $\begin{array}{c}126(7) \mathrm{c} \\
36(2) \mathrm{c} \\
7(4) \mathrm{c} \\
59(9)\end{array}$ \\
\hline
\end{tabular}

${ }_{1}^{1}$ Cane $=$ Carex nebrascensis; June $=$ Juncus nevadensis; Dece $=$ Deschampsia caespitosa $;$ Posa $=$ Poa sandbergii $;$ Arca $=$ Artemisia cana $;$ Artr $=$ A tridentata var. vaseyana . ${ }^{2}$ Grazing treatment by community type, grazing treatment by cover class, and grazing treatment by location analyses were conducted. Neither interaction terms nor grazing treatment effects were significant $(P<0.05)$ for any of the analyses; therefore, we have presented means averaged over grazing treatments. Different letters indicate treatment separation $(P \leq 0.05)$ within rows.

less available (Kauffman et al. 1983). Our results however, showed no difference in use of the willow cuttings between early and late season grazing.

The grazing intensity of this study may have maintained an adequate forage standing crop to prevent heavier use of willow cuttings during the late grazing season compared to the early season grazing. Skovlin (1984) reported that intensity of use may be more important to riparian vegetation maintenance than season of use.

Planting location was the best indicator of willow planting survival in that the highest mean survival $(83 \%)$ could be achieved by simply planting into the streambottom. The closer the cuttings were to the water table the higher the soil moisture and planting survival (Table 5). Poor stream terrace survival precludes the establishment of wide willow corridors along most streams, although some situations may warrant planting longer cuttings into the water table (York 1985). Eckert (1975) measured $90 \%$ survival for willows planted within 30 to $90 \mathrm{~cm}$ of the water table and no survival for cuttings $180 \mathrm{~cm}$ from the water table. Platts et al. (1987) and Schultze and Wilcox (1985) advise not planting willows in a high permanent water table because of reduced growth. In this study leader length followed a pattern similar to survival, the wetter the site the longer the leaders, although the differences were not significant. Generally, the base of willow cuttings in the streambottoms were at the mean water table depth.

As would be expected, community types were not uniformly distributed across streamchannel locations. This point must be considered when interpreting willow survival. The Nebraska sedge/Nevada rush community type had the highest willow survival, followed by the bareground community type, and then the tufted hairgrass/Nebraska sedge community type. These commun- ity types had $68 \%, 37 \%$, and $34 \%$, respectively, of their samples at the streambottom location. The bareground and tufted hairgrass/Nebraska sedge community types had $58 \%$ and $31 \%$ respectively, of their sample locations on the streambank. The Nebraska sedge/Nevada rush and tufted hairgrass/Nebraska sedge community types had about the same mean soil moisture but willow planting survival in the Nebraska sedge/Nevada rush community type was significantly higher. Both these community types had about the same number of samples in each cover class. Apparently competition is related to the species of the competitors and soil moisture is not the only factor involved. Other authors have reported that competition for space, light, moisture, and nutrients may decrease planting survival (Platts et al. 1987, Monsen 1983, Patterson et al. 1981).

The bareground community type had the deepest mean water table and the lowest mean soil moisture of the 3 community types. However, there was more total leader length for the bareground community type than for the other 2 community types, indicating that factors other than soil moisture influenced leader growth. The $0-5 \%$ cover class had a significantly longer leader length than the other cover classes presumably because a large number of the $0-5 \%$ samples were from bareground sites. The 2 sagebrush community types, located primarily on the stream terraces, had significantly deeper water tables relative to the other community types, and only $2 \%$ planting survival. Cover class was not a good indicator of survival and survival appeared to be related to community type and soil moisture factors.

\section{Recommendations}

Even during the 2 drought years of this study, willow cuttings were successfully established in moderately grazed pastures. However, the establishment of a "willow corridor" extending very far 
from the streambottom appears unlikely. Second year survival of 83 and $76 \%$ could be achieved by planting into streambottom sites or Nebraska sedge/Nevada rush community types, respectively. Response of individual species may vary; however, the Geyer's willow used in this study was not adversely affected by waterlogged conditions, as has been reported for some other species. It appears that successful establishment of Geyer's willow can be achieved by planting in locations where the base of the cutting is within 20 to 30 $\mathrm{cm}$ of the water table during mid-summer.

\section{Literature Cited}

Brakensiek, D.L., H.B. Osborn, and W.J. Rawls. 1979. Field manual for research in agricultural hydrology. Agr. Handb. 224. USDA-SEA.

Eckert, R.E. 1975. Improvement of mountain meadows in Nevada. USDIBLM Res. Rep. ARS, Reno, Nev.

Fege, A.S. 1983. The practices and physiological basis of collecting storing and planting Populus hardwood cuttings. In: Short rotation intensive culture: twelve years research. USDA-Forest Service Gen. Tech. Rep. NC-91. North Central Forest Exp. Sta., St. Paul, Minn.

Fege, A.S., and G.N. Brown. 1984. Carbohydrate distribution in dormant Populus shoots and hardwood cuttings. Forest. Sci. 30:999-1010.

Gray, R.L., R. Snieckus, and G. Wilcox. 1984. Riparian revegetation in California, p. 26-32. In: Cal-Neva Widl. Trans. Western Section Wildlife Society and California-Nevada Chapter American Fisheries Society, Reno, Nev.

Haydock, K.P., and N.H. Shaw. 1975. The comparative yield method for estimating dry matter yield of pasture. Australian J. Exp. Agr. Anim. Husb. 15:663-670.

Kauffman, J.B., and W.C. Krueger. 1984. Livestock impacts on riparian ecosystems and streamside management implications...a review. J. Range Manage. 37:430-438.

Kaufiman, J.B., W.C. Krueger, and M. Vavra. 1983. Effects of late season cattle grazing on riparian plant communities. J. Range Manage. 36:685-691.

Marlow, C.B. 1987. Controlling riparian damage with little forage loss. Montana Agr. Exp. Sta., Montana Agrosearch. 2:7.

Monsen, S.B. 1983. Plants for revegetation of riparian sites within the Intermountain region, p. 83-89. In: S.B. Monsen and N. Shaw (eds.) Managing Intermountain rangelands-improvement of range and wildlife habitats. USDA-Forest Serv. Gen. Tech. Rep. INT-157. Intermountain Forest and Range Exp. Sta., Ogden, Utah.

Munz, P.A., and D.D. Keck. 1959. A California flora. Univ. of California Press, Berkeley.
Patterson, D.W., C.U. Finch, and G.I. Wilcox. 1981. Streambank stabilization techniques used by the Soil Conservation Service in California, $p$. 452-458. In: R.E. Warner and K.M. Hendrix (eds.) California riparian systems: ecology, conservation, and productive management. Univ. of California Press, Berkeley.

Petersen, L.A., and H.M. Phipps. 1976. Water soaking pretreatment improves rooting and early survival of hardwood cuttings of some Populus clones. USDA-Forest Serv. Tree Planters' Notes. 27:12-22.

Platts, W.S., W.F. Megahan, and G.W. Minshall. 1983. Methods for evaluating stream, riparian, and biotic conditions. USDA-Forest Serv. Gen. Tech. Rep. INT-138. Intermountain Forest and Range Exp. Sta., Ogden, Utah.

Pintts, W.S., C. Armour, G.D. Booth, M. Bryant, J.L. Bufford, P. Culpin, S. Jensen, G.W. Lienkaemper, G.W. Minshall, S.B. Monsen, R.L. Nelson, J.R. Sedell, J.S. Tuhy. 1987. Methods for evaluating riparian habitats with applications to management. USDA-Forest Serv. Gen. Tech. Rep. INT-221. Intermountain Forest and Range Exp. Sta., Ogden, Utah.

Roath, L.R., and W.C. Krueger. 1982. Cattle grazing influence on a mountain riparian zone. J. Range Manage. 35:100-103.

Rosgen, D.L. 1985. A stream classification system, p. 91-95. In: R.R. Johnson, C.D. Ziebell, D.R. Patton, P.F. Ffolliott, and R.H. Hamre (eds.) Riparian ecosystems and their management: reconciling conflicting uses. USDA-Forest Serv. Gen. Tech. Rep. RM-120. Rocky Mountain Forest and Range Exp. Sta., Fort Collins, Colo.

SAS Institute. 1985. SAS/STAT guide for personal computers. SAS Institute Inc. Cary, N.C.

Schultze, R.F., and G.I. Wilcox. 1985. Emergency measures for streambank stablization: an evaluation, p. 59-61. In: R.R. Johnson, C.D. Ziebell, D.R. Patton, P.F. Ffolliott, and R.H. Hamre (eds.) Riparian ecosystems and their management: reconciling conflicting uses. USDAForest Serv. Gen. Tech. Rep. RM-120. Rocky Mountain Forest and Range Exp. Sta., Fort Collins, Colo.

Skovlin, J.M. 1984. Impacts of grazing on wetlands and riparian ha bitat: a review of our knowledge, p. 1001-1103. In: Developing strategies for rangeland management. Westview Press, Boulder, Colo.

Taylor, D.M. 1986. Effects of cattle grazing on passerine birds nesting in riparian habitat. J. Range Manage. 39:254-258.

VanHaveren, B.P., and W.L. Jackson. 1986. Concepts in stream riparian rehabilitation, p. 280-289. In: Trans. of the 51st North Amer. Wildl. and Natur. Resources Conf. Wildl. Manage. Inst., Washington, D.C.

Volny, S. 1984. Riparian stands. Develop. in Agr. and Managed-forest Ecology. 14:423-453.

York, J.C. 1985. Dormant stub planting techniques, p. 513-514. In: R.R. Johnson, C.D. Ziebell, D.R. Patton, P.F. Ffolliott, and R.H. Hamre (eds.) Riparian ecosystems and their management: reconciling conflicting uses. USDA-Forest Serv. Gen. Tech. Rep. RM-120. Rocky Mountain Forest and Range Exp. Sta., Fort Collins, Colo. 